\title{
INVESTIGATION OF AESTHETIC PREFERENCE THE SIMPLICITY AND THE COMPLEXITY OF THE VISUAL QUALITIES OF MOTIFS IN ISLAMIC ARCHITECTURE
}

\author{
Massud Wahdattalab \\ Assistant Professor, School of Architecture and Urbanism, University of Tabriz Islamic Art University, \\ Tabriz, Iran \\ Amin Nikmaram \\ M.A in Architecture, School of Architecture and Urbanism, University of Tabriz Islamic Art University, \\ Tabriz, Iran
}

\begin{abstract}
Simplicity and complexity are opposite concepts, which seems to be the one causing another loss and unlike other concepts of art in almost all natural and man-made phenomena are in several grades and can become things of beauty and pleasantness. As a human achievement, architecture to respond to the needs and aesthetic preferences of its users, the results of evaluating the effects of motif with simple and complex traits can be of interest for architects and designers. The purpose of this research is to understand that this taste and aesthetic preferences of people who are designers or architects for their design tends towards simplicity or the complexity? This tendency is related to age, sex, education, and social trends there? Is it simply a tendency or complexity in all activities and places his presence is constant or varies according to space and activity? This research is a descriptive study, survey and correlation. Reading methods for data collection, documentation used, as well as to evaluate designs with a variety of activities from a questionnaire survey method is used. The study population consisted of 400 residents of the city of Tabriz in 4 ages, 4 level of education and 4 religious beliefs were considered to describe population variables knowledge of society, statistics descriptive name and to check variable keys connection this research of data analyze for aesthetic preferences, according to the opinion of the participants major statistics using spss software ver.19 are used.) Findings show that people prefer that their buildings are designed by architects for this rather simple, and simplicity in the design of religious buildings, official, sports and leisure and home there.
\end{abstract}

Keywords: simplicity, complexity, aesthetic, motif, Iranian-Islamic architecture.

\section{INTRODUCTION}

The concept of complexity in architecture could be defined on the basis of its opposition to simplicity or indeed what is obvious and primary. Von Meiss, Pierre (2004) indicates that "when the elements are categorized in a way that inspire more than one deduction to the viewer and it is what is called complexity" (Von Meiss, Pierre, 2004:58). He introduces ways to deal with complexity among which we could point to perversity of norms, divergence or asymmetry, anomaly of regular pattern or deviation from familiar forms (same: 60). Simplicity is in contrast with complexity: Simplicity, an attraction of simple forms, lines, circles, spheres, cubes, pyramids and so on which have lasted for thousands of years. In some cases, when the complex structures are easily converted to simplicity, we capture a sort of satisfaction, peace and praise. Gombrich beliefs that simplicity is essentially tied to the culture of the West Classic. In the East we could still find the traces of these simple and concise forms: from Isfahan Jameh Mosque to Zen Art. Spiritual happiness arising from simplicity is probably related to our inside physiological and perceptual preferences. Recognition of the border between simplicity and banality is ambiguous. There are 
major latent differences between beauty and prettiness! Simplicity in architecture and urban design is acquired only by a graceful and pretty solution. Voltaire declares "Beauty is always simple but everything that is simple is not always beautiful" (same: 66). The Kandinsky hypothesis states that basic shapes such as circle, triangle and rectangle are very beautiful in some colors (specified colors) (Jacobsen, 2002).

Birkhoff (1932) defined the relation between order and complexity in mathematical term. He indicated that beauty increases with regulation and reduces with complexity. He described order based on repetition and redundancy and complexity was an expression of diversity. The Eysenck studies (1941\&1942) on the relation between aesthetic computed by Birkhoff formula in 1932 and participants rating on beauty indicated that both order and complexity participated as positive factors in perception of beauty (Machado, et al., 2015).

Ferith \& Nias used the variation in complexity in their studies. The information theory approach made it possible for them to provide objective measurements from a complex patter. However most respondents preferred a medium level of complexity (Berlyne, 1970). Theorists have long believed that two aspects of complexity including diversity and order, are effective in creation of beauty. From this perspective, it could be said that beauty appears from "unity in diversity" (Tatarkiewicz, 1972).

Berlyne (1970\&1971) was probably the first person who offered appropriate psychological explanations for effects of complexity. According to Berlyne framework (theoretical) order is not orthogonal with complexity, given that mess as a sort of complexity was intended with some elements. Several studies were conducted to test this hypothesis (using various visual stimuli). Recent researches showed that their results are highly dependent on the way in which complexity is defined, manipulated or measured (Nadal, Munar, Marty, \& Cela-Conde, 2010).

Berlyne (1974) analyzed other psychological variables existing in this area such as severity and frequency, brightness and clarity, saturation and size. The factor of color was introduced as a visual stimuli in primary processing (Zeki, 1980) and a factor affecting the aesthetic preferences (Martindale \& Moore, 1998). The concept of complexity is considered as an important variable in aesthetic of form. Berlyne believes that complexity of motif increases with increasing the number of elements that exist independently in it. With regard to Berlyne Theory in response to aesthetic presented in 1974, we explain that sense of satisfaction experienced by viewers about an object will increase with enhanced level of desired complexity. Then the desired level reverses and gradually decreases with increased level of resulted complexity (Bruni\&Luigi Porta, 2007:130).

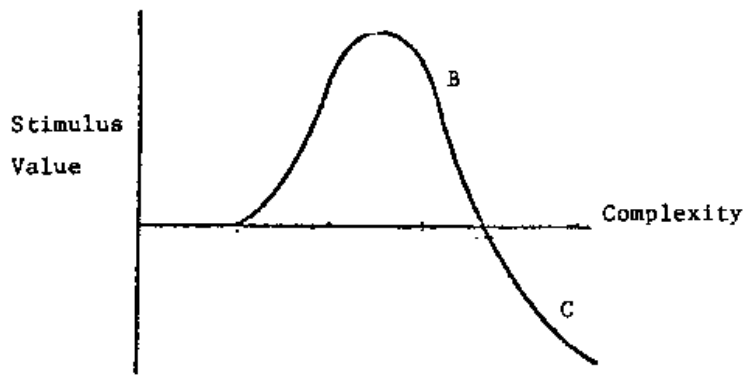

Figure 1. The assumed relation between complexity and given effect by Wundt Curve Source: Berlyne, 1971:193

Since simplicity and complexity are the two ends of a spectrum and a similar relationship is established between them with beauty, we can generalize the Berlyne theory by saying that increased simplicity / complexity can increase the beauty of an object or effect to an extent. This effect reverses when the effect transgresses this limit. There is a relationship between simplicity and complexity in understanding the 
beauty of architecture which makes the addressee feel the beauty inspired by the relation. The beauty is understandable and achievable by both methods of simplicity and complexity, but its extent and rate follows certain elements. The interference of these elements makes a work which claims to be beautiful to change into a banal work. Sometimes a complicated work changes into a crowded and ambiguous object due to the ignorance of contributing elements (Farsi Mohammadi Poor).

The theory of Aesthetic Response was also studied in other areas including Aitken studies on random polygons (1974), Munsinger \& Kessen studies on superiority of language (1964), Nicki\& Gale studies on use of artificial artwork (1977), Saklofske studies on painting human visages which are all revealing the relationship between pleasure and complexity (1975) (M. Messinger, 1998:558).

\section{RESEARCH METHODOLOGY}

The present research is a descriptive (non-experimental) and correlation survey study. Data were collected through three methods: Reading, documents and theoretical foundations in a way that the reading method was used to develop theoretical foundations of research, the field method with survey was used to determine the dimensions of aesthetic and elegancy of motifs with a variety of practical activities of subjects. The descriptive and inferential statistic was used for data analysis. The descriptive statistic was used to describe the demographic characteristics of the sample population, the data analysis as well as aesthetic preference of motifs methods were used to investigate the suitability and relevance of key variables of the study. The inferential statistic using SPSS Software ver.19 was used on the basis of subjects' idea.

To determine the validity of tools content, the ideas of professors and professionals experienced in the subject were considered. With regard to these individuals' ideas, the final questionnaire was distributed among the sample. The Cronback's alpha was used to determine the reliability of the questionnaire. The Cronback's alpha of all questionnaire items was equal to 0.695 by SPSS Software ver.19 which signifies the internal correlation between questions and data. So the reliability of the questionnaire data was pleasant and the data was validated.

\begin{tabular}{|c|c|}
\hline Number of Cases & Cronbach's alpha \\
\hline 18 & 0.695 \\
\hline
\end{tabular}

Table 1- Valid Statistics- Source: SPSS Software, ver.19

\begin{tabular}{|c|c|c|c}
\hline \multirow{2}{*}{} & $\begin{array}{c}\text { Type of } \\
\text { data }\end{array}$ & Number & Percent \\
\cline { 2 - 4 } & $\begin{array}{c}\text { Validated } \\
\text { data }\end{array}$ & 279 & $69.8 \%$ \\
\cline { 2 - 4 } & $\begin{array}{c}\text { Invalidated } \\
\text { data }\end{array}$ & 121 & $30.2 \%$ \\
\cline { 2 - 4 } & Total data & 400 & $100 \%$ \\
\hline
\end{tabular}

Table 2- Summary of data processing-Source: SPSS Software, ver.19

The variables of this research were divided into two groups of dependent and independent variables. The dependent variables in present research include tendency towards complexity (or simplicity) and independent variables include sex, level of education, age and religious beliefs.

Sex: sex was measured at binary nominal scale and options included men and women. 
Level of Education: Educational level was measured at nominal ordinal scale and the options and related values included illiterate, high school diploma, diploma, associate's degree, bachelor's, master 's and Ph.D.

Age: Age was measured at ordinal scale and the options included under 15, 15 to 25 years, 25 to 35 years, 35 to 45 years and above 45 years.

Religious Beliefs: Religious beliefs was measured at ordinal scale and the options included irreligious, normal and religious.

\section{Statistical Population- Sample and Implementation Method}

The Subjects were 400 residents of Tabriz among which 84 people were between 0 to 15 years age range (41 females and 43 males), 72 people were in 15 to 25 years age range (36 females and 36 males), 84 people in 25 to 35 years age range ( 42 females and 42 males), 61 people in 35 to 45 years age range (30 females and 31 males) and 99 people were in age range of over 45 years ( 49 females and 50 males).

\begin{tabular}{|c|c|c|c|c|}
\hline \multirow[t]{2}{*}{ Age Range } & \multicolumn{2}{|c|}{ Men } & \multicolumn{2}{|c|}{ Women } \\
\hline & $<$ ڤ & $\stackrel{0}{\frac{9}{3}}$ & $\stackrel{0}{=}$ & $<\frac{0}{3}$ \\
\hline 0 to 15 years & 43 & $10.75 \%$ & $10.25 \%$ & 41 \\
\hline 15 to 25 years & 36 & $9 \%$ & $9 \%$ & 36 \\
\hline 25 to 35 years & 42 & $10.50 \%$ & $10.50 \%$ & 42 \\
\hline 35 to 45 years & 31 & $7.75 \%$ & $7.50 \%$ & 30 \\
\hline Over 45 years & 50 & $12.50 \%$ & $12.25 \%$ & 49 \\
\hline Sum & 202 & $50.5 \%$ & $49.5 \%$ & 198 \\
\hline
\end{tabular}

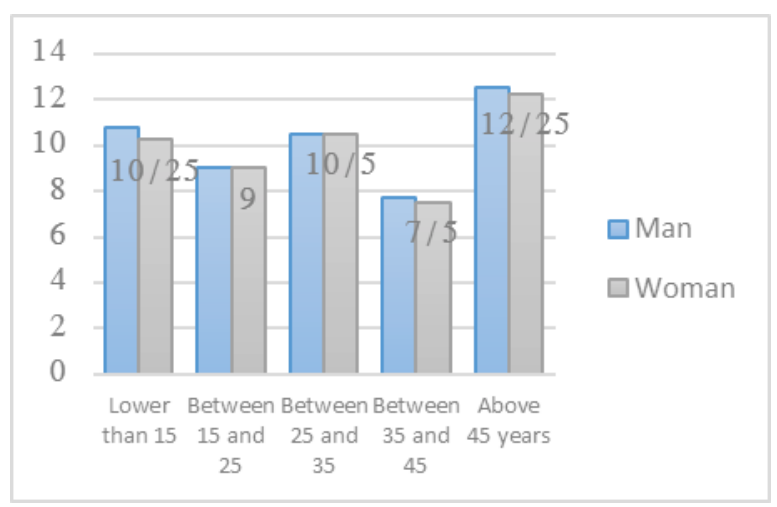

\section{Research Hypothesis}

This research possess one major and 3 secondary sub-hypotheses which are all supplementary in one direction. The hypotheses are as follows: to verify these hypotheses, several questions were designed which are to be described as follows: 


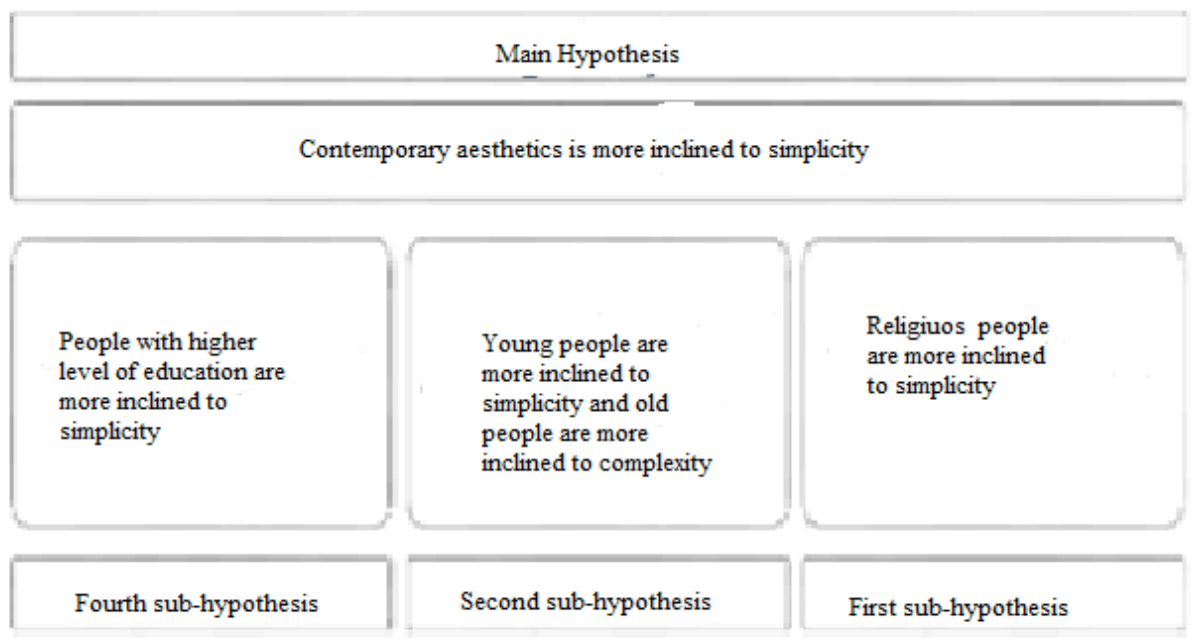

\section{Procedure}

The motifs used in this research belongs to Islamic era which are at almost average level in terms of simplicity and complexity. The questionnaires tested 5 criteria which lead to the simplicity and complexity of motifs as follows: Color (cold and hot with tonality in 1 and 2 rows), delicacy and coarseness of the joints (row 3), elegance and thickness of joints with twists (row 4), increasing and decreasing the number of elements and details of motifs (row 5), increasing and decreasing the number of elements and details of motifs with twist (row 6).

Each of the motif rows were manipulated with move to the left toward complexity and the move to right toward simplicity. Reduced extraneous elements, removed angles and corners and summarized designs were used to simplify the designs. The numerous and complex compression elements, the plurality of angles and sub- components were also used to make the designs more complex.

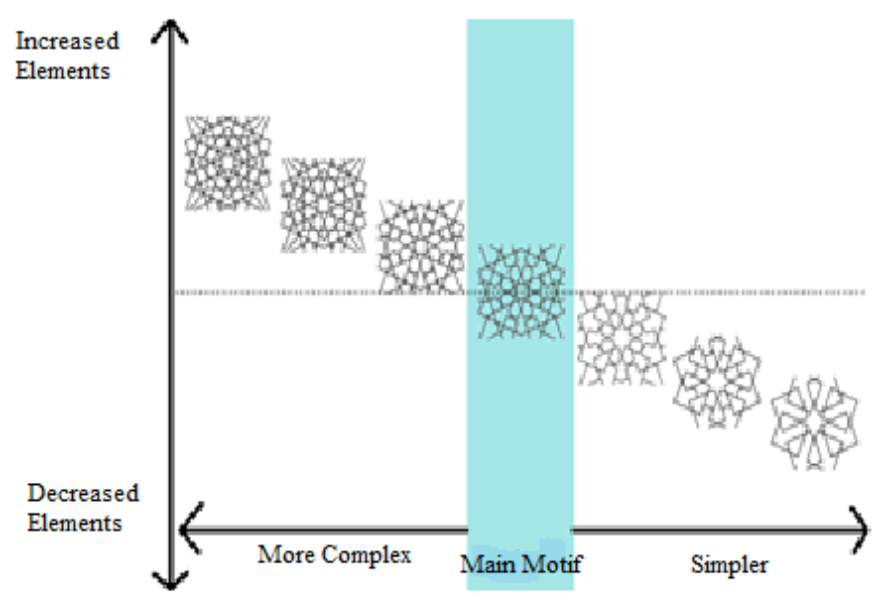

Diagram 2. Movement of simplicity and complexity in tested motifs-Source: authors

\section{Questionnaire}

The applied questionnaire included the three following parts:

First part: Personal background of respondents such as age range, sex, level of education and religious beliefs (optional) 


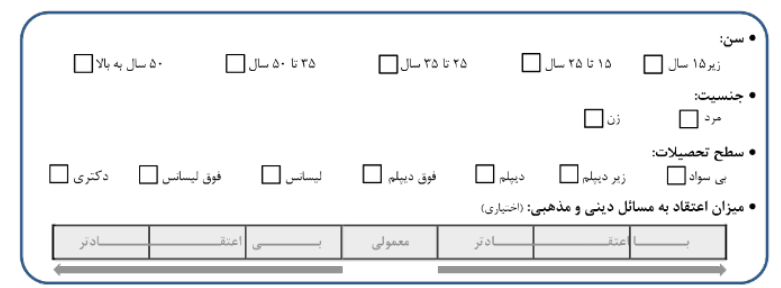

Figure 1. First part of questionnaire-Source: authors

Second part: This part includes a set of questions about respondents' sense of beauty and aesthetic. Among the motifs presented in the third section of the questionnaire, the best and most beautiful motifs were to be selected for desired activities (administrative, educational, residential, sports and religious) which assess the suitability (fitness) of designs for different spaces and functions (administrative, educational, residential, sports and religious).

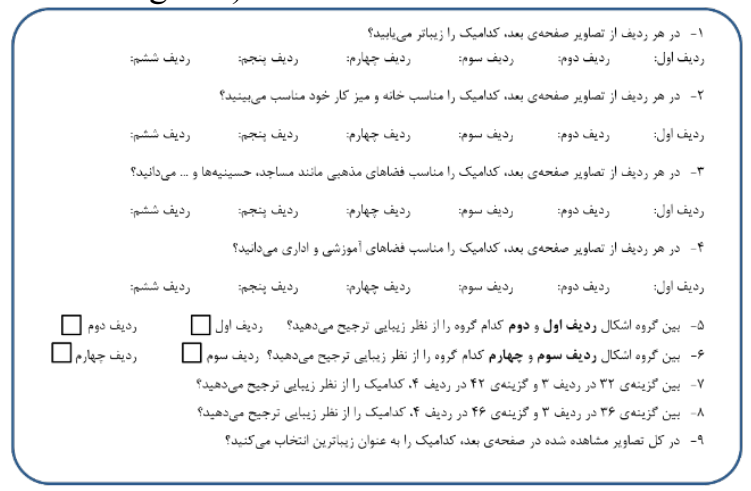

Figure 2. Second part of questionnaire-Source: authors

Third part: It includes 6 manipulated rows which represent 5 pairs of contradictory traits as follows: soft and sharp lines, elegant and rough lines, few and numerous elements, the right way and distortion, chromatic cool and warm colors.

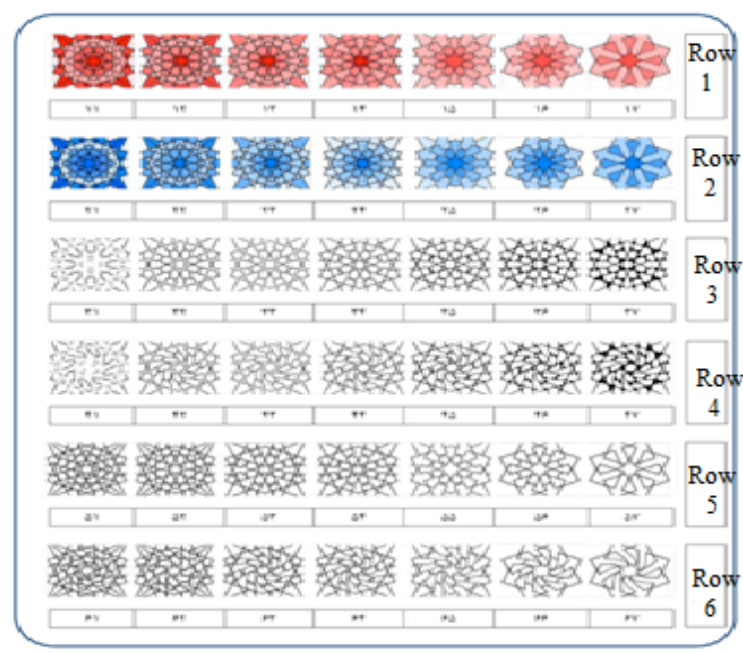

Figure 3. Third part of questionnaire-Source: authors 


\section{Results of Questionnaire Analysis by SPSS Software, ver.19}

According to the sampling and questionnaire data, the index or mean criterion was calculated for each question. (Numbers representing each form are only to identify the shapes and are achieved based on a nominal scale).

$\mathrm{q} 1, \mathrm{q} 2, \mathrm{q} 3$ and $\mathrm{q} 4$ are variables respectively introduced for means answered in questions 1, 2, 3 and 4 .

$\mathrm{S} 1, \mathrm{~S} 2, \mathrm{~S} 3$ are qualitative variables reflecting the tendency to simplicity and complexity in questions 1,2 , 3 and 4 and each is a grouped variable with two 0 and 1 groups.

q5 to q8 were introduced for questions 5 to 8 on the basis of nominal scale with 0 and 1 codes. Descriptive statistics were calculated for variables of questions 5 to 8 which include central and dispersion indices. The mean value with only two amounts of 0 and 1 (questions 5 to 8 ) identifies the ratio of samples with code 1 .

The skewness for variable 5 is negative and close to zero (skewness to leaf). It is positive and close to zero for other variables (skewness to right), however its rate is not too high. Besides, the kurtosis or Chamfer frequency curve compared to normal standard curve is negative for all negative variables (Chamfer frequency curve).

According to the abundance table of Question 5,61\% of second row figures and $37.5 \%$ of people prefer the first row figures. Since the figures differ only in color, so we come to conclusion that aesthetic sense of modern people is more inclined toward cold colors.

\begin{tabular}{|c|c|c|c|c|c|}
\hline \multicolumn{6}{|c|}{ Question 5} \\
\hline & & Frequency & Percentage & $\begin{array}{l}\text { Validated data } \\
\text { percentage }\end{array}$ & $\begin{array}{l}\text { Cumulative } \\
\text { percentage }\end{array}$ \\
\hline \multirow{3}{*}{$\begin{array}{c}\text { Available } \\
\text { data }\end{array}$} & First row & 150 & 37.5 & 38.1 & 38.1 \\
\hline & Second row & 244 & 61 & 61.9 & 100 \\
\hline & Sum & 394 & 98.5 & 100 & \\
\hline Lost data & No response & 6 & 1.5 & & \\
\hline \multicolumn{2}{|c|}{ Total } & 400 & 100 & & \\
\hline
\end{tabular}

Table 5. Frequency of question 5-Source: SPSS Software, ver.19

In question 6, with regard to frequency table, the figures of third row with the highest point $(57.5 \%)$ are higher than frequency percentages of fourth row (41.2\%). The respondents assessed the right figure motifs more beautiful than tilted motifs in terms of aesthetic aspects.

\begin{tabular}{|c|c|c|c|c|c|}
\hline \multicolumn{6}{|c|}{ Question 6} \\
\hline & & Frequency & Percentage & Validated data percentage & Percentage \\
\hline \multirow[t]{3}{*}{$\begin{array}{c}\text { Available } \\
\text { data }\end{array}$} & $\begin{array}{l}\text { Third } \\
\text { row }\end{array}$ & 230 & 57.5 & 58.2 & 58.2 \\
\hline & $\begin{array}{l}\text { Fourth } \\
\text { row }\end{array}$ & 165 & 41.2 & 41.8 & 100 \\
\hline & Sum & 395 & 98.8 & 100 & \\
\hline Lost data & $\begin{array}{c}\text { No } \\
\text { response }\end{array}$ & 5 & 1.2 & & \\
\hline \multicolumn{2}{|c|}{ Total } & 400 & 100 & & \\
\hline
\end{tabular}

Table 6. Frequency of question6- Source: SPSS Software, ver.19

In question 7, 68\% of respondents preferred figure 2 in row 3 which confirms the results of question 6.

Question 7 


\begin{tabular}{|c|c|c|c|c|c|}
\hline & $\begin{array}{c}\text { Frequenc } \\
\mathrm{y}\end{array}$ & $\begin{array}{c}\text { percentag } \\
\mathrm{e}\end{array}$ & $\begin{array}{c}\text { Validated data } \\
\text { percentage }\end{array}$ & $\begin{array}{c}\text { percentag } \\
\mathrm{e}\end{array}$ \\
\hline $\begin{array}{c}\text { Availabl } \\
\text { e data }\end{array}$ & $\begin{array}{c}\text { Number 2 } \\
\text { Row 3 }\end{array}$ & 272 & 68 & 68.2 & 68.2 \\
\cline { 2 - 6 } & $\begin{array}{c}\text { Number 2 } \\
\text { Row 4 }\end{array}$ & 127 & 31.8 & 31.8 & 100 \\
\cline { 2 - 6 } & Sum & 399 & 99.8 & 100 & \\
\hline $\begin{array}{c}\text { Lost } \\
\text { data }\end{array}$ & $\begin{array}{c}\text { No } \\
\text { response }\end{array}$ & 1 & 0.2 & & \\
\hline \multicolumn{2}{|c|}{ Total } & 400 & 100 & & \\
\hline
\end{tabular}

Table 7. Frequency of question 7-Source: SPSS Software, ver.19

In question $8,59.5 \%$ of respondents selected figure 6 in row 3. So we come to the conclusion that soft angles of motif cannot attract the attention of survey respondents in relation to the selection of distorted motifs. Right motifs are still in beautiful shape.

\begin{tabular}{|c|c|c|c|c|c|}
\hline \multicolumn{6}{|c|}{ Question 8} \\
\hline & & Frequency & Percentage & Validated data percentage & Percentage \\
\hline \multirow[t]{3}{*}{ Available data } & $\begin{array}{c}\text { Number } 6 \\
\text { Row } 3\end{array}$ & 238 & 59.5 & 59.8 & 59.8 \\
\hline & $\begin{array}{c}\text { Number } 2 \\
\text { Row } 4\end{array}$ & 160 & 40 & 40.2 & 100 \\
\hline & Sum & 398 & 99.5 & 100 & \\
\hline Lost data & No response & 2 & 0.5 & & \\
\hline \multicolumn{2}{|c|}{ Total } & 400 & 100 & & \\
\hline
\end{tabular}

Table 8. Frequency of question 8-Source: SPSS Software, ver.19

Since both variables are based on the nominal scale, Phi and Cramer's correlation coefficient were used to obtain a correlation between color (hot and cold colors) and sex (male and female). According to the results in the below table, we see that the ratio of men who selected the second row (cool colors) was more than women in this statistical population. In other words women preferred warm colors and men preferred cool colors in terms of aesthetic aspects.

\begin{tabular}{|c|c|c|c|c|}
\hline \multicolumn{5}{|c|}{ Response to question 5 distinguished by sex } \\
\hline \multicolumn{5}{|c|}{ Number } \\
\hline & & \multicolumn{2}{|c|}{ Sex } & \multirow[t]{2}{*}{ Sum } \\
\hline & & woman & $\operatorname{man}$ & \\
\hline \multirow[t]{2}{*}{$\begin{array}{c}\text { Question } \\
5\end{array}$} & $\begin{array}{l}\text { First } \\
\text { row }\end{array}$ & 77 & 73 & 150 \\
\hline & $\begin{array}{c}\text { Second } \\
\text { row }\end{array}$ & 116 & 128 & 244 \\
\hline \multicolumn{2}{|c|}{ Sum } & 193 & 201 & 394 \\
\hline
\end{tabular}

Due to the constant coefficient of Phi and Cramer and a significance level less than 0.05, (Table 9) the hypothesis of independency of these two variables is rejected. So there is a relationship between sex and choice of hot and cold colors.

\begin{tabular}{|l|l|l|c|}
\hline & Value & $\begin{array}{c}\text { Approximate } \\
\text { significance } \\
\text { level }\end{array}$ \\
\hline
\end{tabular}

Submit Date: 21.06.2016, Acceptance Date: 23.07.2016, DOI NO: 10.7456/1060AGSE/038

Copyright (C) The Turkish Online Journal of Design, Art and Communication 


\begin{tabular}{|c|c|c|c|}
\hline $\begin{array}{c}\text { Nominal- } \\
\text { Nominal }\end{array}$ & $\begin{array}{c}\text { Fi } \\
\text { coefficient }\end{array}$ & 0.037 & 0.0465 \\
\cline { 2 - 4 } & $\begin{array}{c}\text { Cramer } \\
\text { coefficient }\end{array}$ & 0.037 & 0.0465 \\
\hline $\begin{array}{c}\text { Number of available } \\
\text { cases }\end{array}$ & 394 & \\
\hline
\end{tabular}

Table 9. Symmetrical actions- Source: SPSS Software, ver.19

\section{Hypothesis Testing}

After describing variables and responses obtained from the population, this section examines the hypotheses raised in statistical tests used in the study in order to evaluate the accuracy of our assumptions and prove the verity or untruth of proposed hypothesis by data analysis.

Hypothesis 1: Contemporary aesthetics is more inclined to simplicity.

$\mathrm{H}_{0}$ (Null Hypothesis): In terms of contemporary aesthetics, there is no difference between average of people inclined to simplicity and complexity.

$\mathrm{H}_{1}$ (Alternative hypothesis): In terms of contemporary aesthetics, there is a difference between average of people inclined to simplicity and complexity and this tendency is more towards simplicity.

The result is summarized in following table: The table shows the statistical group of T-test independent samples. This table contains the number of cases, the mean value, standard deviation and standard error test variables defined in conjunction with the categories defined by the group variable (simple and complex). Given that we want to compare the average of the two groups it would be useful to know the average values.

The aesthetic sense of people was evaluated according to figures in question 1.228 people were interested in simple shapes and the average score given to question 1 was equal to 5.87 which is more than the standard mode (score 5) set to distinguish between simplicity and complexity.

Table 10. Statistical group-Source: SPSS Software-ver.19

\begin{tabular}{|c|c|c|c|c|c|c|}
\hline & & 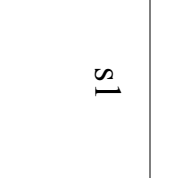 & 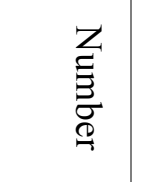 & 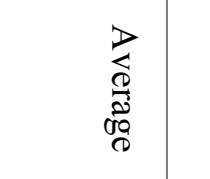 & 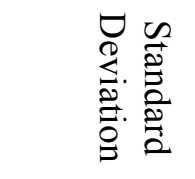 & 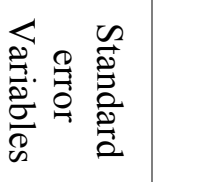 \\
\hline \multicolumn{7}{|c|}{ Summary of processed cases } \\
\hline & \multicolumn{6}{|c|}{ Cases } \\
\hline & \multicolumn{2}{|c|}{ Available data } & \multicolumn{2}{|c|}{ Lost data } & \multicolumn{2}{|r|}{ Sum } \\
\hline & Number & Percentage & Number & Percentage & Number & Percentage \\
\hline $\mathrm{q} 5 * \operatorname{Sex}$ & 394 & $98.5 \%$ & 6 & $1.5 \%$ & 400 & $100 \%$ \\
\hline \multirow{2}{*}{$\begin{array}{c}\text { Question } \\
1\end{array}$} & \multicolumn{2}{|c|}{ Complexity } & 172 & 3.305 & 1.1336 & 0.0864 \\
\hline & \multicolumn{2}{|c|}{ Simplicity } & 228 & 5.871 & 0.6535 & 0.0433 \\
\hline
\end{tabular}

The above instructions creates two different tests between the two groups of tendency towards simplicity and complexity. The Levene statistic tests this hypothesis. In the first test (first row) it is assumed that the variance of the two groups is equal. Since the significant level of first Levene's test is the small $(<0.05)$, we use the results which did not assume the equality of variances or the second row in other words. 
With regard to significance level, the null hypothesis related to equality of variances is rejected. Now the results of the second row shows a small level of significance for T-test. This small level of significance $(<0.05)$ shows that there is significant difference between two groups (tendency to simplicity and complexity) and rejects the null hypothesis. The important thing here is that there is a close relationship between confidence interval and hypothesis testing. The diagram shows the difference between the groups (tendency to simplicity and complexity).

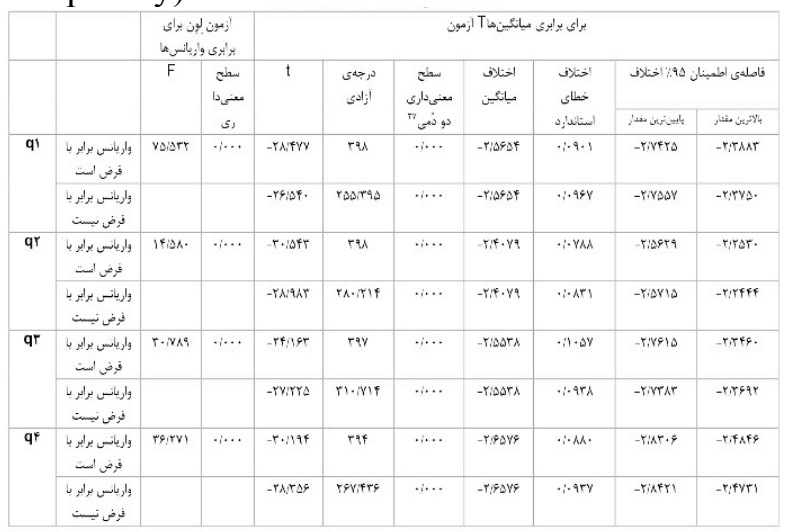

Table 11. Dependent T-test-Source: SPSS Software, ver.19

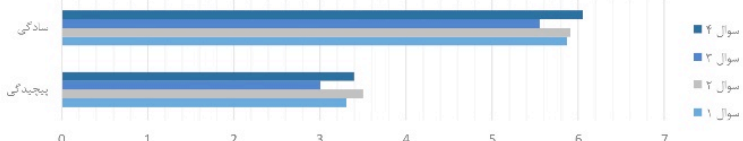

\begin{tabular}{|c|c|c|c|c|c|c|c|}
\hline \multicolumn{8}{|c|}{ 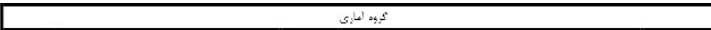 } \\
\hline$\frac{2}{t}$ & كرغبية & 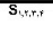 & تعداد & بائنين & استاندارد & 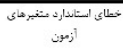 & ترفيباتبات \\
\hline$-\frac{c^{7}}{\mathrm{r}}$ & زيباشناختى معاصر بيشتر به سمت سادمى & بيتيدئن & $\begin{array}{ll}r r \\
r r_{n}\end{array}$ & $\begin{array}{l}r i r \cdot \Delta \\
\Delta: X V Y\end{array}$ & 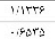 & $\begin{array}{l}\because 18 \mathrm{sq} \\
\cdots \mathrm{Fr}\end{array}$ & قبول \\
\hline$-\frac{3}{4}$ & اقراد در محيط كار وخانه كرايش بهسادىى & بيجيدئي & $\begin{array}{l}191 \\
\pi 74\end{array}$ & 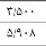 & 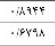 & 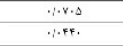 & قبول \\
\hline $1+\frac{C}{t}$ & 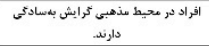 & | بيجيدئك & $\frac{d r v}{i r r}$ & $\begin{array}{l}r i \cdots f \\
\Delta ; \Delta \Delta r\end{array}$ & 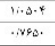 & $\begin{array}{l}-1.991 \\
+1.999\end{array}$ & قبول \\
\hline$\rightarrow \frac{C^{\prime}}{T^{2}}$ & 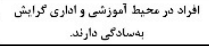 & W & $\begin{array}{l}194 \\
r \%\end{array}$ & 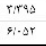 & $\begin{array}{l}1.014 \\
.8999 .\end{array}$ & $\begin{array}{l}\%-1 \% \\
\cdots * 4 ;\end{array}$ & قبول \\
\hline
\end{tabular}

\section{Hypothesis 2: The religious people show more tendency to simplicity.}

$\mathrm{H}_{0}$ : (Null hypothesis): Different groups (in terms of belief) show no differences in terms of tendency toward simplicity and complexity. Religious beliefs have no effect on the type their point of view.

$\mathrm{H}_{1}$ : (Alternative hypothesis): there is significant differences between different groups of faith and the tendency to simply. According to null hypothesis, the average willingness of the population in three groups is the same in terms of religious beliefs. Therefore we study contemporary aesthetics (in terms of tendency to simply and complexity) among all religious groups Using ANOVA.

Table 12 shows the descriptive statistics (mean tendency to simplicity, standard deviation and standard error). Among total 400 samples, 6 people were irreligious, 117 people were normal and 170 were religious. The average tendency towards simplicity in irreligious and ordinary people groups (in terms of belief) were nearly identical. But the mean value was more in religious group.

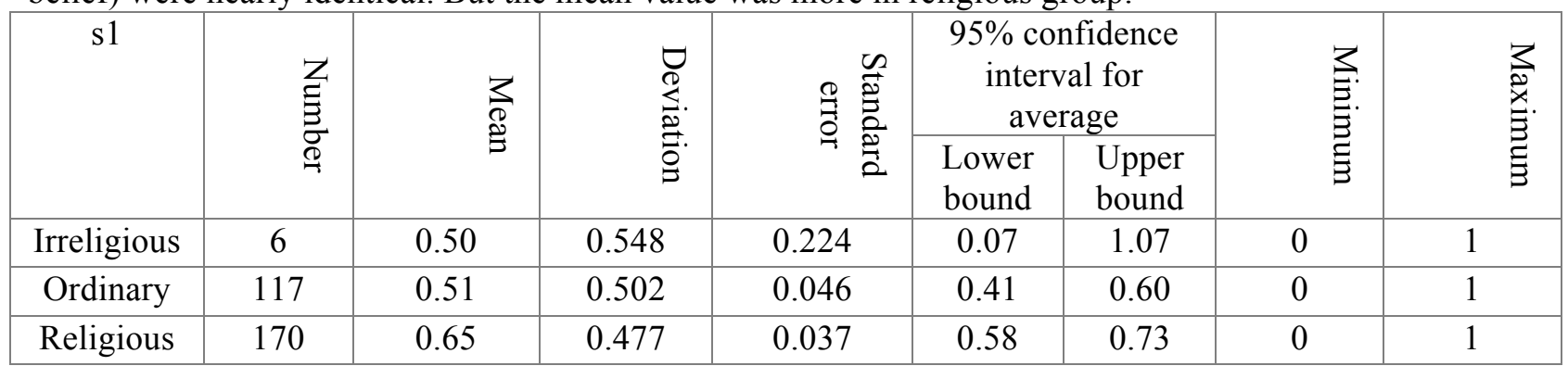




\begin{tabular}{|c|c|c|c|c|c|c|c|c|}
\hline Sum & 293 & 0.59 & 0.493 & 0.029 & 0.53 & 0.65 & 0 & 1 \\
\hline
\end{tabular}

Table 12. Descriptive Statistics-Source: SPSS Software, ver. 19

Table 13 of Levene Statistics, null hypothesis, rejects the equality of variances due to the significance level of 0.002 which is lower than 0.05 .

\begin{tabular}{|c|c|c|c|}
\hline s1 & \multicolumn{3}{|c|}{} \\
\hline Levene & Variance & Variance & $\begin{array}{c}\text { Level of } \\
\text { Statistics }\end{array}$ \\
\hline 6.270 & 2 & 2 & significance \\
\hline
\end{tabular}

Table 13. Variance equality test-Source: SPSS Software, ver.19

Decision on the authenticity of null hypothesis could be achieved on the basis of comparison of dispersion between two estimates of inter-group and intra-groups. Since the intra-group comparison estimate was sufficiently smaller than inter-group estimates and the F value (ration of inter-group mean square to intragroup mean group) was more than 1 and with regard to significance level of 0.038 , we reject the null hypothesis (Table14).

\begin{tabular}{|c|c|c|c|c|c|}
\hline s1 & Sum of squares & Level of freedom & Square mean & $F$ & Level of significance \\
\hline Intera-group & 1.582 & 2 & 0.791 & 3.311 & 0.038 \\
\hline Inter-group & 69.271 & 290 & 0.239 & & \\
\hline Sum & 70.853 & 292 & & & \\
\hline
\end{tabular}

Table 14.Variance analysis- SPSS Software, ver. 19

So there is significance difference between different belief groups and level of tendency toward simplicity. The religious beliefs affect the insight of people.

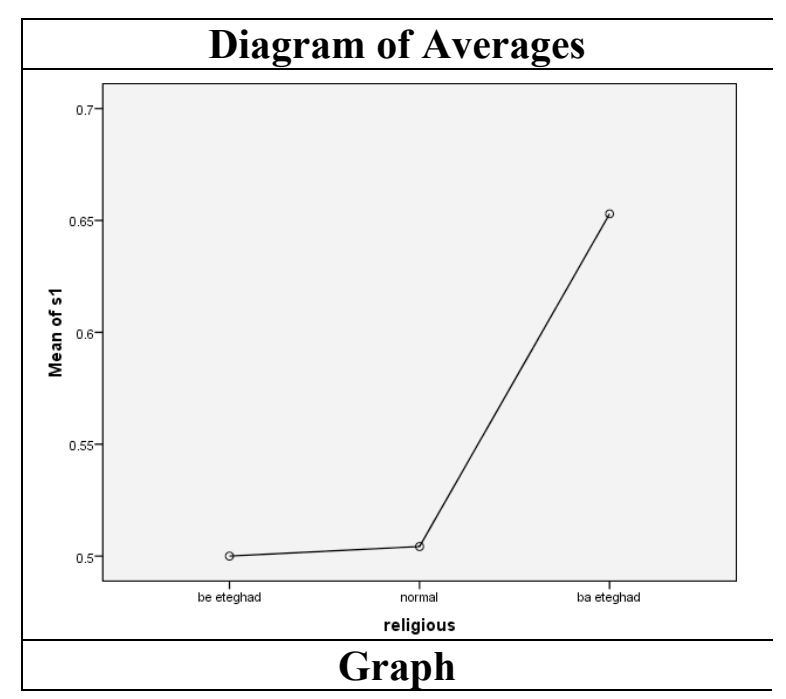




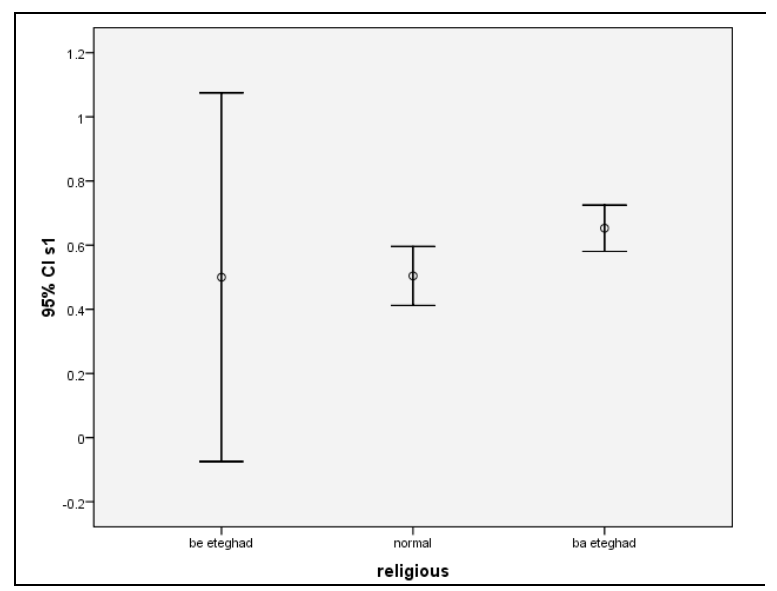

After rejecting the null hypothesis, the multiple comparison was used to define the difference. Ben Ferroni is one of the simplest multiple methods shown in following table.

\begin{tabular}{|c|c|c|c|c|c|c|}
\hline \multicolumn{7}{|c|}{ s1 Ben Ferroni } \\
\hline \multirow[b]{2}{*}{ 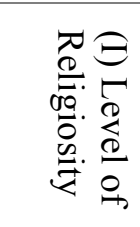 } & \multirow[b]{2}{*}{ 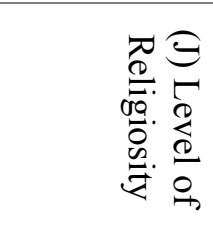 } & \multirow[b]{2}{*}{ 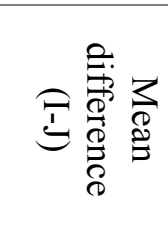 } & \multirow[b]{2}{*}{ 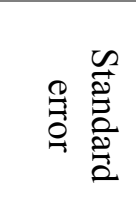 } & \multirow[b]{2}{*}{ 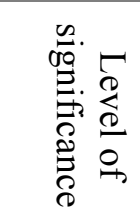 } & \multicolumn{2}{|c|}{$95 \%$ confidence interval } \\
\hline & & & & & Lower bound & Upper bound \\
\hline \multirow{2}{*}{ 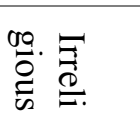 } & Normal & -0.004 & 0.205 & 1.000 & -0.50 & 0.49 \\
\hline & Religious & -0.153 & 0.203 & 1.000 & -0.64 & 0.34 \\
\hline \multirow{2}{*}{ 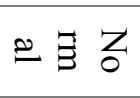 } & Irreligious & 0.004 & 0.205 & 1.000 & -0.49 & 0.50 \\
\hline & Religious & $-0.149 *$ & 0.059 & 0.036 & -0.29 & 0.00 \\
\hline \multirow{2}{*}{ 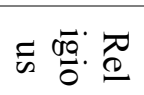 } & Irreligious & 0.153 & 0.203 & 1.000 & -0.34 & 0.64 \\
\hline & Normal & $0.149^{*}$ & 0.059 & 0.036 & 0.01 & 0.29 \\
\hline
\end{tabular}

Table 15. Ben Ferroni multiple comparison-Source: SPSS Software, ver.19

It is evident that people with more level of religious beliefs (religious) are significantly more inclined to simplicity compared to people with ordinary beliefs. There is no significant difference between the two groups of religious and irreligious people as well as the irreligious and people with ordinary beliefs. So the hypothesis that religious people have more inclinations toward simply is not rejected.

Hypothesis 3: Young people are more inclined to simplicity. The old people are more inclined to complexity.

$\mathrm{H}_{0}$ : (Null hypothesis): Average tendency to simply is equal to average tendency to complexity among different age groups.

$\mathrm{H}_{1}$ : (Alternative hypothesis): There is significant difference between the averages of these tendencies.

The result is shown in following table.

The first table shows the descriptive statistic in all age ranges. 


\begin{tabular}{|c|c|c|c|c|c|c|c|c|}
\hline \multirow[t]{2}{*}{ s1 } & \multirow{2}{*}{ تعداد } & \multirow{2}{*}{ مبانكبن } & \multirow{2}{*}{ انتحراف مبيار } & \multirow{2}{*}{ خطاى استاندارد } & \multicolumn{2}{|c|}{ 907 فاصلى 'طمينان براى ميانكين } & \multirow{2}{*}{ حدافل } & \multirow[t]{2}{*}{ حداكثر } \\
\hline & & & & & كران بايين & كران بالا & & \\
\hline كمثر أز 10 سال & is & $\cdot \Delta r$ & .80 .4 & $\because \Delta f$ &.$* Y$ & .994 & $\cdot$ & 1 \\
\hline بين ها تا هب سال & vr & $\cdot(\Delta r$ & $\cdot \Delta \cdot r$ &.$\% \Delta 9$ & $-* 1$ & .190 & $\cdot$ & 1 \\
\hline بين هY تا هب سال & $\Delta f$ & .190 & $\cdot \pi v A$ & $\% \Delta r$ & $.1 \Delta \Delta$ & $\cdot N G$ & $\cdot$ & 1 \\
\hline بين هب تا فه سال & 91 & $\cdot \Delta F$ & $.18 . r$ & $\therefore .94$ & $* * 1$ & $.19 \mathrm{~V}$ & . & 1 \\
\hline بلاي هـ سال & ax & $\cdot \Delta \wedge$ &.+499 & $\because \Delta$. & $* * 1$ & .191 & $\cdot$ & 1 \\
\hline مجموع & $4 .$. & $\cdot i \Delta r$ &. $\mid x q 4$ & $\%$ r &.$\Delta r$ & $.19 r$ & . & 1 \\
\hline
\end{tabular}

Table 16. Descriptive studies- Source: SPSS Software, ver.19

Table 17 of Levene statistics rejects the null hypothesis of equality of variance groups (the significance level is less than 0.05 ).

\begin{tabular}{|c|c|c|c|}
\hline s1 & & & \\
\hline Levene Statistics & df1 & df2 & Level of significance \\
\hline 4.684 & 4 & 395 & 0.001 \\
\hline
\end{tabular}

Table17. Test of Homogeneity of Variances- Source: SPSS Software, ver.19

The F statistics and its related significance level is shown in Table 16 . We cannot reject the null hypothesis because the significance level of 0.434 is more than 0.05 and the $\mathrm{F}^{34}$ ratio is close to one $(0.952)$ which shows that the null hypothesis is correct because both of them are an estimate of population variance.

\begin{tabular}{|c|c|c|c|c|c|}
\hline s1 & sum of squares & $\begin{array}{c}\text { Level of } \\
\text { freedom }\end{array}$ & $\begin{array}{c}\text { Mean } \\
\text { Square }\end{array}$ & F Statistics & Level of significance \\
\hline Intra-group & 0.937 & 4 & 0.234 & 0.952 & 0.434 \\
\hline Inter-group & 97.103 & 395 & 0.246 & & \\
\hline Sum & 98.040 & 399 & & & \\
\hline
\end{tabular}

Table 18. Analysis of variance- Source: SPSS Software, ver. 19

The Ben Ferroni in table 19 shows that there is not a significant difference between the groups in terms of their tendency to simplicity and complexity, because none of the pairs are significant in the columns of mean difference. None of the pairs are significant so age difference has no effect on the change of aesthetic tendency towards simplicity or complexity. The hypothesis which says that young people are more inclined to simplicity and older people are more inclined to complexity is rejected. 


\begin{tabular}{|c|c|c|c|c|c|c|}
\hline $\begin{array}{c}\text { با فرونى } \\
\text { بن }\end{array}$ & & & & & & \\
\hline \multirow[t]{2}{*}{ سن (l) } & \multirow[t]{2}{*}{ سن (J) } & \multirow[t]{2}{*}{ اختلاف ميانكينين(J-) } & \multirow[t]{2}{*}{ خطاى استاندارد } & \multirow[t]{2}{*}{ سطح منى دارى } & \multicolumn{2}{|c|}{ 90: فاصلدى اطمينان } \\
\hline & & & & & كران بايين & كران بالا \\
\hline \multirow[t]{4}{*}{ كمتر 'ز 10 سال } & بين 10 تا هr سال & $\% r$ & $\% \times 9$ & $1 \ldots \cdots$ & $-\pi / \pi$ & $\cdot \pi r$ \\
\hline & بين هY ثا هب سال & 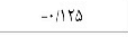 & $\because v y$ & $11 \cdots$ &.$- \pi 4$ & .1 .9 \\
\hline & بين هب تا هب سال &..$- \cdot 1 r$ & $\cdot \cdot \lambda \mu$ & $11 \cdots$ & $-\pi r \Delta$ & $\cdot \pi r$ \\
\hline & بالاى هـ سال & $-\cdot \cdot \Delta r$ & $\% \cdot r r$ & $11 \cdots$ & $-\pi \varphi$ & .119 \\
\hline \multirow[t]{4}{*}{ بين 10 تا هr سال } & كمتر از ها سال & $-\cdot \cdot \cdot r$ & $\% \times 9$ & $11 \cdots$ & $-\pi / r$ & $\cdot \pi r$ \\
\hline & بين هץ ثا هץ سال & 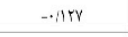 & $\because \lambda \cdot$ & $1 \cdots \cdots$ & $-\pi \Delta$ & $\cdot n$ \\
\hline & بين هr تا هو سـال & $-\cdot+\cdot 14$ & 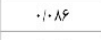 & $11 \cdots$ & $-\pi / 4$ & $\cdot \pi r$ \\
\hline & بالاى هـ سال & $-\cdot t \cdot \Delta f$ & $\because \cdot \mathrm{VV}$ & $11 \cdots$ & $-* \pi r$ & .119 \\
\hline \multirow[t]{4}{*}{ بين هب تا ها سال } & كمتر از 10 سال & . ATS & $\because v y$ & $11 \cdots$ &.$- \cdot \% 9$ & $\cdot \pi 4$ \\
\hline & بين Qا تا هT بال & - ATY & $\because \cdot \lambda$ & $11 \cdots$ & $-\cdot 11$ & .40 \\
\hline & بين هt تا هF سال & . 1114 & $\cdot \lambda r$ & $11 \cdots$ & $-* / 1 r$ & $\cdot \pi \Delta$ \\
\hline & بالاي هـ سال & $\% \cdot r r$ & $\therefore \cdot v F$ & $1, \cdots$ &.$- / 1 r$ &.$\pi \mu$ \\
\hline \multirow[t]{4}{*}{ بين هץ تا هـ سال } & كمتر أز ها سال & $\because \cdot 14$ & $\cdot \cdot \lambda r$ & $11 \cdots$ & $-\pi / T$ & $\cdot \pi \Delta$ \\
\hline & بين ها تا هY سال & $\% \pi$ & $\because \cdot 19$ & $1, \cdots$ & $-\pi r$ & .149 \\
\hline & بين هY تا هب سال & $-m l f$ & $\cdot \cdot \lambda \mu$ & $11 \cdots$ & $-\pi \Delta$ & . Ar \\
\hline & بالاى هf سال &.-++41 & $\cdot \cdot \lambda 1$ & $11 \cdots$ & $-\pi r y$ & .119 \\
\hline \multirow[t]{4}{*}{ بالاي هز سال } & كمتر أز 10 سال & $\% \Delta r$ & $\cdot \cdot \nabla r$ & $11 \cdots$ & -.119 & .149 \\
\hline & بين 10 تا هY سال & $\% \Delta f$ & $\cdot * \mathrm{Vr}$ & $11 \cdots$ & -.119 & $\cdot \pi V$ \\
\hline & بين QT تا هT سال & $-\cdot * \cdot v r$ & $\% \cdot v e$ & $1, \cdots$ & $-\pi \mu$ &.$A r$ \\
\hline & بين هt تا هF سال & $* * * 1$ & $\cdot \cdot \lambda \|$ & $11 \cdots$ & $-\cdot / 19$ & $\cdot \pi Y$ \\
\hline
\end{tabular}

Table 19. Multiple comparison- Source: SPSS Software, ver. 19

\section{Hypothesis 4: the more educated people have more tendency to simplicity}

There is no statistical significance difference between individuals' aesthetic preferences and their level of education, however this difference is significant in home environment, office and educational spaces. It seems that people with higher level of education have more tendency towards simplicity at home and working places. This tendency is toward complexity in people with very high or very low educational degree. The difference is not also significant amongst different educational groups in educating places (in terms of level of significance). 


\begin{tabular}{|c|c|c|c|c|c|c|c|c|c|}
\hline & & \multirow[t]{2}{*}{ تعناد } & \multirow[t]{2}{*}{ 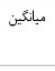 } & \multirow[t]{2}{*}{ التحر ان معيار } & \multirow[t]{2}{*}{ خطاث استانثارد } & \multicolumn{2}{|c|}{ ه9: خاصلى اطمينان براي ميانكين } & \multirow[t]{2}{*}{ حناقل مقدار } & \multirow[t]{2}{*}{ حناكثر متنار } \\
\hline & & & & & & كران بايين & كران بالا & & \\
\hline \multirow[t]{8}{*}{ s! } & بيسواث & 4 & 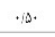 &.$\Delta f A$ & irt4 & $-+\% \cdot \gamma$ & $1 \because \cdot r$ & . & 1 \\
\hline & زير دبيلم & 10. & $\cdot / \Delta \omega$ & .799 & $+(+4$ & 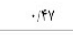 & .194 & . & 1 \\
\hline & دببله & Ar & $\cdot / \Delta \Delta$ & $.8 \cdot 1$ & $\because \Delta \Delta$ & .144 & .99 & $\cdot$ & 1 \\
\hline & فوقدبيلم & ar & $\cdot / \Delta r$ & $\cdot \theta \cdot \Delta$ & $\because \cdot \mathrm{vA}$ & $\cdot \pi \mathrm{T}$ & $.9 A$ & . & 1 \\
\hline & ليسانس & Ar & .199 & 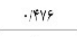 & $\because \Delta r$ & $\cdot 109$ & $\cdot w$ & . & 1 \\
\hline & فوقئبسان & iq & .94 & .799 & $\because \cdot 9 v$ &.+1 & : $A \mathrm{Ar}$ & . & 1 \\
\hline & دكنى & 1 &.$/$. & $\ldots \cdots$ & $\because \cdots$ & $+\cdots$ & $\therefore \cdots$ & . & . \\
\hline & مجموع & pq. &.$\Delta V$ & .790 & $\because \% \Delta$ & $\cdot \Delta r$ & 194 & . & 1 \\
\hline \multirow[t]{8}{*}{ sr } & بي بواث & 4 & $.9 \mathrm{Y}$ & i(B) & $-\pi 11$ &.$/ 4 r$ & $\operatorname{lin}$ & . & 1 \\
\hline & زير ديبلم & 10. & $\cdot \mid \Delta \psi$ & $.8 .$. & $\because+4$ & .149 & .94 & . & 1 \\
\hline & ديبله & $A Y$ & $\cdot \Delta V$ & .79 .1 & $\because \Delta \Delta$ &.+14 & .91 & . & 1 \\
\hline & فوقد دبيلمه & Ar & .94 & Fas & $\because v_{\Delta}$ & 1,79 & -179 & $\cdot$ & 1 \\
\hline & لبسانس & Ar &.$; 99$ &.$\$ 4 y$ & .1 .81 & $\cdot / \Delta \mathrm{A}$ & .179 & . & 1 \\
\hline & فوقليساتس & t8 & .198 & Fha & $\because 4 \Delta$ &.$* 4$ & $\cdot i n s$ & . & 1 \\
\hline & دكثرى & 1 & $1 / \cdot$ & $\ldots \cdots$ & $\because \cdots$ & $; \cdots$ & $+\cdots$ & 1 & 1 \\
\hline & مجموع & rq. &.$\xi$ & .791 & $\because+\Delta$ & .100 & .198 & . & 1 \\
\hline \multirow[t]{8}{*}{ sr } & بيسواث & 4 & $\ldots$ & $\ldots$ & $+\cdots$ & $\because \cdot$ & $\because \cdot \cdot$ & . & . \\
\hline & زيب دببلم & 10. & $r s$ & $\pi y \lambda$ & $1 \% 49$ & $\cdot \pi V$ & $.14 \mathrm{rr}$ & . & 1 \\
\hline & ديبلم & $A r$ & .79 &.$\mp \Delta \lambda$ & $.4 \Delta$ & .119 & .179 & . & 1 \\
\hline & فوقدببيلم & ir & .79 & $F \Delta \Delta$ & $\because \cdot n$ & . 114 & 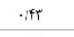 & $\cdot$ & 1 \\
\hline & لبسانس & Ar & $\pi$ & $* * 49$ & $* \Delta r$ & $\cdot \pi r$ & .144 & . & 1 \\
\hline & فوفنيساتس & ty & .119 & .F.Y. & $\because \cdot v_{9}$ & $\%+$ & .178 & . & 1 \\
\hline & دكنرى & 1 & $\because \cdot$ & $; \cdots$ & $\because \cdots$ & $\cdot \cdot \cdot$ & $\because \cdot \cdot$ & . & . \\
\hline & مجموع & rq. & $m$ &.$* 45$ & 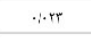 & . its & $*$ & . & 1 \\
\hline \multirow[t]{8}{*}{$\mathbf{s f}$} & بيسواث & 4 &.$\pi T$ &.$\$ 19$ & $2 \pi 11$ & $-+\pi i$ & $\cdot \operatorname{siM}$ & . & 1 \\
\hline & زيبر دبيلم & 179 & $\cdot / \Delta \Delta$ & .799 & $-1+41$ & . FY & $.9 \%$ & . & 1 \\
\hline & ديبلم & Ar & Irigy & $11 . \pi 9 \lambda$ & Irisy & $-11 \Delta 9$ & r9:9. & . & 999 \\
\hline & فوقدبيلم & Fr & . $\mathrm{Ny}$ & $n \cdot$. & $: 4 \mathrm{v}$ & . $* 4$ & 171. & . & v \\
\hline & لبسانس & Ar & $1 \% ; 99$ & $1.9 .0 \mathrm{Ar}$ & $\mid r i \cdot r h$ & $-11, \pi 9$ & $r 9,91$ &. & ११९ \\
\hline & فوقنيسانس & iq & $\cdot N V$ & .45 & $* \mu^{*}$ & . & .199 & $\cdot$ & 1 \\
\hline & دكنرى & 1 & $1 / \cdot$ & $\therefore \cdots$ & $\therefore \cdots$ & $\because \cdot$ & $\because \cdot$ & 1 & 1 \\
\hline & مجموع & raq & aNT & YIFq9 & risro & $-1: f$ & Wrise & . & 999 \\
\hline
\end{tabular}

Table 20. Descriptive statistics- Source: SPSS Software, ver.19

\begin{tabular}{|c|c|c|c|c|}
\hline & آماره لون & Idf & rdf & سطح معنى دارى \\
\hline is & $\varphi / . . r^{a}$ & $\Delta$ & rar &.$/ \cdots 1$ \\
\hline is & $\varphi / \& 4 \Delta^{b}$ & $\Delta$ & rیז & $\cdot / \cdots$ \\
\hline rs & $1 \cdot / 994^{c}$ & $\Delta$ & rیז & $\cdot / \cdots$ \\
\hline is & $4 / 1 / q^{d}$ & $\Delta$ & rat & $.1 \cdot 94$ \\
\hline \multicolumn{5}{|c|}{ SI S كروهها تنها با ناديده كرفتن يك مورد در محاسبهى آزمون همكنى واريانس براى a } \\
\hline \multicolumn{5}{|c|}{ S كروهها تنها با ناديده كرفتن يك مورد در محاسبهى آزمون همكنى واريانس براى Sr b } \\
\hline \multicolumn{5}{|c|}{ 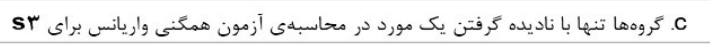 } \\
\hline \multicolumn{5}{|c|}{ 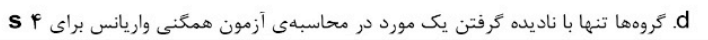 } \\
\hline
\end{tabular}

Table 21. Homogeneity of variance test-Source: Spss Software 


\begin{tabular}{|c|c|c|c|c|c|c|}
\hline & & مجموع مربعها & درجهى أزادى & مربع ميانكين & $F$ & سطح منى دارى \\
\hline \multirow[t]{3}{*}{ s) } & بين كروهى & $|\pi N|$ & 4 & . irif & $\cdot 1 / 49$ & $.181 Y$ \\
\hline & درونكروهى & $9 F_{1} \cdot .4 T$ & rir &.$\pi 49$ & & \\
\hline & مجهوع & QWiTf & $r \wedge 9$ & & & \\
\hline \multirow[t]{3}{*}{ sr } & بين كروهى & 1/.099 & 9 & $\pi \varphi$ & $1 / \cdot \lambda f$ & $\because r V I$ \\
\hline & درونكووهى & MYi. ry & rar &.$\pi \%$ & & \\
\hline & مجموع & $94,8 .$. & rAq & & & \\
\hline \multirow[t]{3}{*}{ sr } & بين كروهى & $1, x+4$ & 4 & . mYY & 11.48 & $\therefore \times 90$ \\
\hline & درونكُوهى & Arillt & rit & . $\pi i f$ & & \\
\hline & مجموع & $\Delta \pi / f \Delta 9$ & $r \wedge 9$ & & & \\
\hline \multirow[t]{3}{*}{ sf } & بين كروهى & IFATNTAT & 9 & rT. 9 TrVD & $.4 \% \mathrm{~V}$ & $\cdot: A * y$ \\
\hline & درونكئوهى & $1999994 \pi \cdot 0$ & rAT & 0109119. & & \\
\hline & مجموع & $19 \lambda r \Delta \cdot r, 9 \Delta \lambda$ & $r M$ & & & \\
\hline
\end{tabular}

Table 22. Analysis of variance-Source: Spss Software
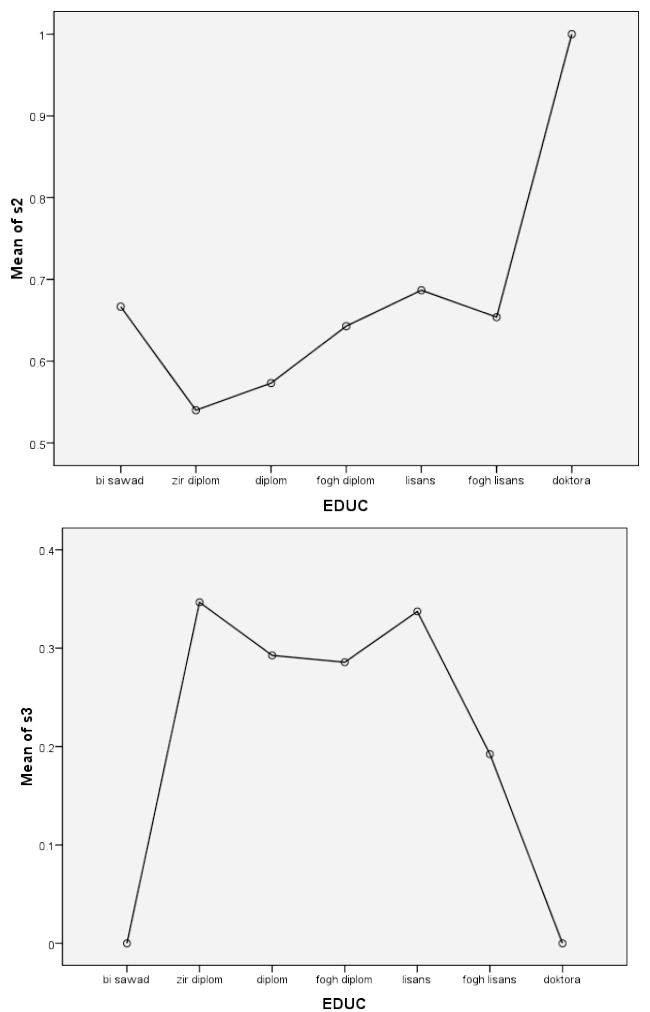

\section{CONCLUSION}

According to this study, contemporary aesthetics is more inclined towards simplicity. With regard to the point that 1 to 7 grades were regarded for each of the figures applied in the questionnaire from left to right, and grade 5 was set as the interval between simple and complex motifs and the mean degree was equal to 5.87 which is more than the standard grade (grade 5), so the hypothesis that contemporary aesthetics is more inclined toward simplicity is verified. According to present study, people with more religious beliefs have more tendency towards simplicity. In fact the average tendency of people to simplicity is almost identical in both groups of religious people and people with ordinary beliefs (in terms of belief), however the average value is higher in religious group. The Levene statistics obtained for null hypothesis denies the equality of variances in different groups. There is significant difference between diverse groups in terms of belief and tendency toward simplicity and the religious inclinations affect the people's point of view. According to Ben Ferroni comparison, the people with more religious beliefs (religiuos) are more significantly inclined to simplicity compared to the people with ordinary beliefs. Besides, there is 
significant difference between two groups of religious and irreligious as well as irreligiuos and people with ordinary beliefs. So the hypothesis that people with religious beliefs have more tendency to simplicity is not rejected. According to the present study, the young people are not inclined to simplicity. In fact age has no impact in the change of peoples' aesthetic tendency toward simplicity or complexity. The hypothesis that younger people are more inclined to simplicity is rejected. The present study shows that people with higher level of education are more inclined toward simplicity in house and working places. In religious environment, this tendency amongst people with very high or very low educational background is toward complexity. There is also no significant difference between diverse educational groups in educating places.

\section{REFERENCES}

Farsi Mohammadi Pour, Alireza, (2005), the concept of order in the architectural aesthetics, University of Kurdistan, Kurdistan.

Von Meiss, Pierre, (2004), look at the fundamentals of architecture of the form to place, translated by Simon Ayvazian, Publishing Tehran University, Tehran.

Berlyne, D. (1970). Novelty, complexity and hedonic value. Perception and Psychophysics, 8, 279-286.

Berlyne, D. (1971). Aesthetics and Psychobiology. New York: Appleton-Century-Crofts.

Berlyne, D. (1974). Studies in the new experimental aesthetics. New York: Wiley.

Bruni, L., \& Luigi Porta, P. (2007). Handbook on the Economics of Happiness. Massachusetts,USA: Edward Elgar.

Helson, H. (1964). Adaptation-level theory: An experimental and systematic approach to behavior. New York: Harper and Row.

Jacobsen, T. (2002). Kandinsky's questionnaire revisited: Fundamental correspondence of basic color and form. Perceptual and Motor Skills, 95, 903 - 913.

Jacobsen, T. (2002). Kandinsky's questionnaire revisited: Fundamental correspondence of basic color and form. Perceptual and Motor Skills, 95, 903 - 913.

Leder, H., Belke, B., Oeberst, A., \& Augustin, D. (2004). A model of aesthetic appreciation and aesthetic judgments. British Journal of Psychology, 98, 489-508.

M. Messinger, S. (1998). Pleasure and Complexity: Berlyne Revisited. The Journul of Psychology, 558560 .

Machado, P., Romero, J., Nadal, M., Santos, A., Correia, J., \& Carballal, A. (2015). Computerized measures of visual complexity. Acta Psychologica, 160, 43-57.

Martindale, C., \& Moore, K. (1998). Priming, prototypicality, and preference. Journal of Experimental Psychology: Human Perception and Performance, 14(4), 661-670.

Nadal, M., Munar, E., Marty, G., \& Cela-Conde, C. (2010). Visual Complexity and Beauty Appreciation: Explaining the Divergence of Results. Empirical Studies of the Arts, 28, 173-191.

Tatarkiewicz, W. (1972). The great theory of beauty and its decline. The Journal of Aesthetics and Art Criticism, 31, 165-180.

Zeki, S. (1980). The representation of colours in the cerebral cortex. Nature, 284, 412- 418. 